\title{
OPERATIVE RESULT OF RESISTANT CONGENITAL TALIPES EQUINOVARUS CASES: OUR EXPERIENCE
}

\author{
Munin Borgohain 1 , Sanjib Goswami², Amit Rajbongshi ${ }^{3}$
}

${ }^{1}$ Associate Professor, Department of Orthopaedics, FAAMCH, Barpeta.

${ }^{2}$ Assistant Professor, Department of Orthopaedics, FAAMCH, Barpeta.

3 Postgraduate Trainee, Department of Orthopaedics, FAAMCH, Barpeta.

\section{ABSTRACT}

Congenital Talipes Equinovarus is the most common foot deformity and its incidence is approximately one in 1000 live births. ${ }^{1}$ Congenital talipes equinovarus is a complex deformity and has a tendency to recur until the age of six or seven years. ${ }^{2}$ Treatment varies from non-operative method 3 to a variety of surgical techniques. ${ }^{4}$

\section{AIM}

This study aims to assess the results of operative treatment in CTEV cases. It is our humble hope that this work would throw some light on this demanding, resource consuming problems and management in our setup and with our scarce resources.

\section{MATERIALS}

Thirty six patients with sixty deformed feet were taken for one stage posterior medical soft tissue release who were admitted in the Department of Orthopaedic Surgery, Fakhruddin Ali Ahmed Medical College and Hospital, Barpeta, in the year 2011 to 2016 . The average follow-up is 2.8 years.

\section{METHODS}

All patients are treated with manipulation and plaster cast immobilisation prior to surgery. Those who did not respond well to plaster cast technique are subjected for one stage posterior medial soft tissue release.

\section{RESULT}

57 of 60 feet produced successful result according to Pirani score system. Excellent in 13 feet, Good in 36 feet, Unsuccessful result in 3 feet.

\section{CONCLUSION}

In view of successful result in $95 \%$ feet with fewer complications, one stage posterior medial soft tissue release approach merits continued use in cases of resistant congenital Talipes equinovarus.

\section{KEYWORDS}

Congenital Talipes Equinovarus, Rigid, Casting, Release.

HOW TO CITE THIS ARTICLE: Borgohain M, Goswami S, Rajbongshi A. Operative result of resistant congenital talipes equinovarus cases: our experience. J. Evolution Med. Dent. Sci. 2016;5(68):4905-4908, DOI: 10.14260/jemds/2016/1115

\section{INTRODUCTION}

The idiopathic congenital clubfoot is treated by gentle serial manipulation to stretch the contractures and it is maintained by casting, splinting or strapping of the corrected deformity. ${ }^{5}$ The treatment carried out to achieve a functional, pain free, plantigrade foot with good mobility of joints without any calluses. Now-a-days surgery is considered when conservative management has failed. It is considered after 9-12 months of age. This allows proper visualisation of structures and prevent excessive scarring, which is common in Neonate Surgery. 6 Surgical treatment should be delayed if the foot continuously respond to conservative treatment.

Turco $^{7}$ (1971) performed an operation in one stage releasing soft tissue on posterior medial aspect along with internal fixation of talonavicular joint with percutaneous

Financial or Other, Competing Interest: None.

Submission 01-08-2016, Peer Review 03-08-2016,

Acceptance 16-08-2016, Published 25-08-2016.

Corresponding Author:

Dr. Munin Borgohain,

House No-8, Bahniman Path,

Near Jayanagar L. P. School, Beltola-781028,

Guwahati, Kamrup, Assam.

E-mail: deepikagmc08@gmail.com

DOI: $10.14260 /$ jemds $/ 2016 / 1115$
Kirschner's wire. He in 1979 concluded that the best time for operation is 1.5 years. McKay advised for more radial circumferential soft tissue release in medial, lateral, posterior and plantar aspect of the foot to get good result. ${ }^{8}$ Cincinnati incision gives best exposure in postero-lateral and posteromedial aspect, but sometimes there is difficulty in skin closure after surgery. ${ }^{9}$ Use of soft tissue expander before extensive surgery for clubfoot or before revision surgery is extremely helpful.10

The standard postero-medial release with release of Talonavicular joint, calcaneo-fibular joint and interosseous ligament is said as complete subtalar release. Greater degree of correction can be achieved with complete subtalar release along with achievement of alignment of foot and knee. Moreover, the complications are also less. ${ }^{11}$ Complete subtalar release also reduces the angles that are used to measure the equinovarus deformities and talonavicular subluxations. ${ }^{12}$

The child with tarsal and metatarsal bone deformity usually resists the correction. In this condition, combination of soft tissue release and various bony procedures are considered.13,14 In older children between five to eight years of age, the soft tissue procedure is combined with Lichtblau procedure. ${ }^{15}$ In children older than 9 years, the lateral border of foot is shortened and calcaneo-cuboid fusion done.16 
Likewise soft tissue release with medial open wedge osteotomy of calcaneum and insertion of bone wedge is also described. Bony procedure is rarely necessary in infant and young child, as it will disturb the normal growth and development of the foot. 17 Children's with skeletal maturity require osteotomy of calcaneum and tarsal bones and triple arthrodesis required as salvage procedure.18 Metatarsal osteotomy at the base of metatarsal bones will correct varus forefoot. Dwyer's osteotomy of calcaneum will correct hindfoot varus; medial rotational osteotomy of tibia will correct lateral rotational mal-alignment of the tibia and fibula. ${ }^{19,20}$

\section{METHOD}

Thirty six cases of congenital talipes equinovarus with sixty deformed feet were studied in the Department of Orthopaedics, Fakhruddin Ali Ahmed Medical College, Barpeta, from March 2011 to March 2016. Study done regarding Age, Sex, Side involved, religious distribution and post-operative results. All patients are treated with manipulation and plaster cast immobilisation prior to surgery. Cases not responding to conservative treatment are subjected for one stage posterior medial self-tissue release. Preoperatively, the patients were taken for clinical and radiological evaluation. Pre- and post-operative X-ray done both in Antero-Posterior and lateral view for radiological evaluation. Follow-up carried out at 2 weeks interval up to 3 months and then once at 3 months interval up to the age of 3 years and then at 6 months interval up to the age of 5 years. After achieving plantigrade foot, we prescribe a specially designed CTEV shoe and splint. Results were evaluated using the criteria of Pirani Scoring System.

\section{Pirani Scoring}

\begin{tabular}{|c|c|c|c|}
\hline Parameters & Normal & Moderate & Severe \\
\hline Mid Foot & & & \\
Curved Lateral Border & 0 & 0.5 & 1 \\
Medial Crease & 0 & 0.5 & 1 \\
Talar Head Coverage & 0 & 0.5 & 1 \\
\hline Hind Foot & & & \\
Posterior Crease & 0 & 0.5 & 1 \\
Rigid Equinus & 0 & 0.5 & 1 \\
Empty Foot & 0 & 0.5 & 1 \\
\hline
\end{tabular}

In our study the outcomes are excellent, good and poor. Pirani Score 0 means excellent, Pirani Score 0.5 to 1 means good and more than 1 means poor, excellent and good outcomes are combined and called as successful management. Poor outcome means failure of treatment. The collected data are analysed and presented at tables.

\section{OBSERVATION AND RESULTS}

Majority cases (75\%) were between the age group of 6 to 12 months with mean age 12.01 months (Table 1). In our study, male far outnumbered the female (72.22\%) (Table II). Bilateral involvement found in 48 of 60 feet with a percentage of 66.67 (Table III). Fifty two (82.67\%) feet were of rigid variety and $8(13.33 \%)$ feet of non-rigid variety (Table IV); 30 of 36 patients are from Islam religion (83.3\%) (Table V). Cases are more from Islam religion probably due to demographic pattern in the population. The pre-operative average Talo $1^{\text {st }}$ Metatarsal angle was $30^{\circ}$ in antero-posterior view and the average pre-operative Talo Calcaneal angle was $62^{\circ}$ in lateral view (Table VI). After Surgical correction, the final average Talo $1^{\text {st }}$ Metatarsal angle was $16^{0}$ in anterior posterior view and average Talo Calcaneal angle was $42^{\circ}$ in lateral view (Table VII). The mean Pirani Score in the study group was 5.67. There was no significant difference of mean Pirani score of rigid and non-rigid varieties (5.83+Vs 5.31 ) (Table VIII); 57 $(95 \%)$ of 60 feet were managed successfully. Only $3(5 \%)$ feet developed wound dehiscence at the operation site and deformity recurred during the follow-up period and they are marked as unsuccessful result (Table IX and X); 5 of 60 feet developed superficial wound infection and treated adequately with antibiotics and wound healed by dressing. This complication did not affect the final clinical outcome.

\begin{tabular}{|c|c|c|c|}
\hline Group & Age (Month) & No. of Cases & Percentage \\
\hline I & $6-12$ & 27 & $75 \%$ \\
\hline II & $13-24$ & 4 & $11.11 \%$ \\
\hline III & $25-36$ & 4 & $11.11 \%$ \\
\hline IV & $37-48$ & 1 & $2.78 \%$ \\
\hline & Total & 36 & $100.00 \%$ \\
\hline \multicolumn{4}{|c|}{ Table I: Incidence of Age } \\
\hline
\end{tabular}

\begin{tabular}{|c|c|c|}
\hline Sex & No. of Cases & Percentage \\
\hline Male & 26 & $72.22 \%$ \\
\hline Female & 10 & $27.28 \%$ \\
\hline Total & $\mathbf{3 6}$ & $\mathbf{1 0 0 . 0 0 \%}$ \\
\hline \multicolumn{3}{|c|}{ Table II: Incidence of Sex } \\
\hline
\end{tabular}

\begin{tabular}{|c|c|c|}
\hline Side Involved & No. of Cases & Percentage \\
\hline Right & 5 & $13.89 \%$ \\
\hline Left & 7 & $19.44 \%$ \\
\hline Bilateral & 24 & $66.67 \%$ \\
\hline Total & $\mathbf{3 6}$ & $\mathbf{1 0 0 . 0 0 \%}$ \\
\hline \multicolumn{2}{|c|}{ Table III: Incidence of Side } \\
\hline
\end{tabular}

\begin{tabular}{|c|c|c|}
\hline Rigidity & No. of Feet & Percentage \\
\hline Rigid variety & 52 & $86.67 \%$ \\
\hline Non-rigid variety & 8 & $13.33 \%$ \\
\hline Total & $\mathbf{6 0}$ & $\mathbf{1 0 0 . 0 0} \%$ \\
\hline \multicolumn{2}{|c|}{ Table IV: Rigidity of Feet } \\
\hline
\end{tabular}

\begin{tabular}{|c|c|c|}
\hline & No. of Cases & Percentage \\
\hline Islam & 30 & $83.33 \%$ \\
\hline Others & 6 & $16.67 \%$ \\
\hline Total & $\mathbf{3 6}$ & $\mathbf{1 0 0 . 0 0 \%}$ \\
\hline \multicolumn{2}{|c|}{ Table V: Religious Distribution } \\
\hline
\end{tabular}

\begin{tabular}{|c|c|}
\hline View & Angles (Average) \\
\hline $\begin{array}{c}\text { Anterior Posterior } \\
\text { Talo 1 1st MT }\end{array}$ & $30^{\circ}$ \\
\hline Lateral Talocalcaneal & $62^{\circ}$ \\
\hline \multicolumn{2}{|c|}{ Table VI: Initial Radiological Assessment } \\
\hline
\end{tabular}

\begin{tabular}{|c|c|}
\hline View & Angles (Average) \\
\hline $\begin{array}{c}\text { Anterior Posterior } \\
\text { Talo 1 }{ }^{\text {st }} \text { MT }\end{array}$ & $16^{0}$ \\
\hline $\begin{array}{c}\text { Lateral } \\
\text { Talocalcaneal }\end{array}$ & $42^{0}$ \\
\hline \multicolumn{2}{|c|}{ Table VII: Final Radiological Assessment } \\
\hline
\end{tabular}




\begin{tabular}{|c|c|c|c|}
\hline $\begin{array}{c}\text { Pirani } \\
\text { Score }\end{array}$ & $\begin{array}{c}\text { Rigid } \\
\text { Type }\end{array}$ & $\begin{array}{c}\text { Non-Rigid } \\
\text { Type }\end{array}$ & $\begin{array}{c}\text { Total } \\
\text { Feet }\end{array}$ \\
\hline & $\begin{array}{c}\text { No.=52 } \\
(\mathbf{8 6 . 6 7 \% )}\end{array}$ & $\begin{array}{c}\text { No.=8 } \\
(\mathbf{1 3 . 3 3 \% )}\end{array}$ & $\begin{array}{c}\text { No.=60 } \\
(\mathbf{1 0 0 \% )}\end{array}$ \\
\hline 06 & $34(65.38 \%)$ & $2(25 \%)$ & \\
\hline 5.5 & $12(23.08 \%)$ & $3(37.5 \%)$ & \\
\hline 05 & $2(3.85 \%)$ & $2(25 \%)$ & \\
\hline 4.5 & $3(5.77 \%)$ & & $1(12.5 \%)$ \\
\hline 04 & $1(1.92 \%)$ & 0 & \\
\hline 3.5 & 0 & \multicolumn{3}{|c|}{ Table VIII: Initial Pirani Score } \\
\hline \multicolumn{4}{|c|}{}
\end{tabular}

\begin{tabular}{|c|c|c|c|}
\hline $\begin{array}{c}\text { Pirani } \\
\text { Score }\end{array}$ & $\begin{array}{c}\text { Rigid Type } \\
\text { No.=52 (86.67\%) }\end{array}$ & $\begin{array}{c}\text { Non-Rigid Type } \\
\text { No.=8 (13.33\%) }\end{array}$ & $\begin{array}{c}\text { Total } \\
\text { No.=60 (100) }\end{array}$ \\
\hline 1.5 & $3(5.77 \%)$ & & $3(5 \%)$ \\
\hline 1 & $19(36.54 \%)$ & & $19(31.67 \%)$ \\
\hline 0.5 & $17(32.69 \%)$ & $2(25 \%)$ & $19(31.67 \%)$ \\
\hline 0 & $13(25 \%)$ & $6(75 \%)$ & $19(31.67 \%)$ \\
\hline \multicolumn{3}{|c|}{ Table IX: Final Pirani Score } \\
\hline
\end{tabular}

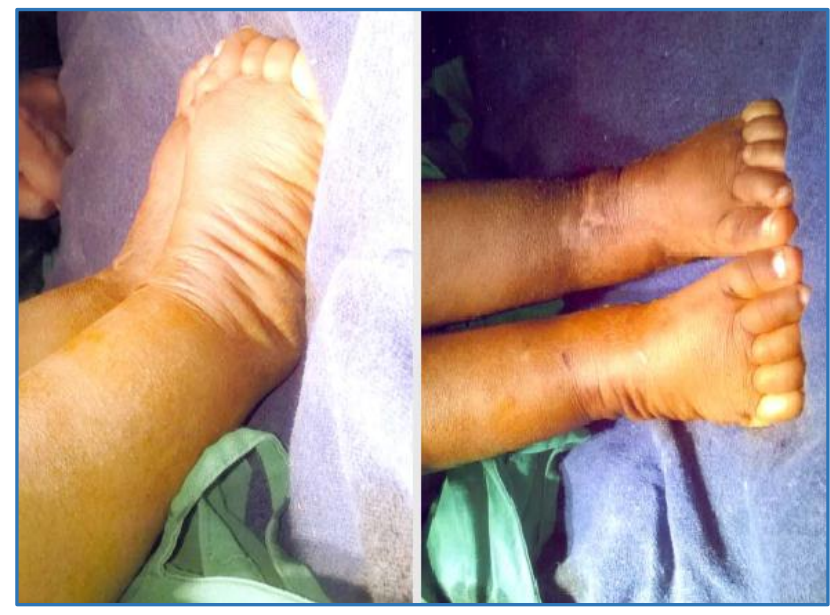

Post-Operative Photograph

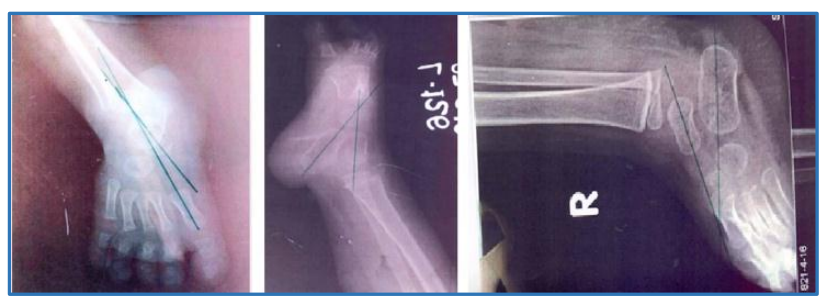

Post-Operative X-Ray

\section{DISCUSSION}

Congenital talipes equinovarus is one of the commonest congenital deformity, which comprises of equinovarus adduction and cavus deformity. It requires meticulous and dedicated effort on the part of both treating surgeon and parents. There are controversy regarding best treatment for CTEV for 2500 years, where Hippocrates proposed for manipulation and splinting. ${ }^{21}$ After treatment, we always try to reduce or eliminate these deformities. The foot must be functional, pain free, plantigrade with good mobility without callosity and does not require to wear modified shoes.

We have selected the patients with long duration of casting, incomplete correction of the deformity, recurrence of deformity and difficulty of treatment of old neglected cases with severe deformity for surgical correction.

The residual hind foot varus or cavus deformity of the heel are most common complication after surgical treatment of CTEV even after use of Talonavicular wires for stabilisation of corrected feet.22 Clinical and radiological assessment of all the cases at periodic internal showed comparable results with other studies using Pirani scoring system. ${ }^{23}$

The Surgical technique provide better control and correction of the foot deformity. By the end of the follow-up period, maximum number of patients showed successful functional result. We think that we should follow the patients for longer duration to get the long term result of the studied patients. We believe that our clinical and radiological values are promising to manage severe CTEV cases.

\section{REFERENCES}

1. Canale ST. Cambell's operative orthopaedics. $10^{\text {th }}$ edn. Vol 2. Philadelphia: Mosby 2003:988-1005.

2. Ponseti IV. Current concept review: treatment of congenital club foot. JBJS Am 1992;74(3):448-54.

3. Kite JH. Non-operative treatment of congenital clubfoot. Clin Orthop Relat Res 1972;84:29-38. 
4. Mckay DW. New concept of and approach to clubfoot treatment: section II-correction of clubfoot. Jour Pediatric Orthop 1983;3(1):10-21.

5. Herzenberg JE, Radler C, Bor N. Ponseti versus traditional method of casting for idiopathic clubfoot. J Pediatr Orthop 2002;22(4):517-21.

6. Ghali NN, Smith RB, Clayden AD, et al. The results of pantalar reduction in the management of congenital talipes equinovarus. JBJS Br 1983;65(1):1-7.

7. Turco VJ. Surgical correction of the resistant club foot. One-stage posteromedial release with internal fixation: a preliminary report. JBJS Am 1971;53(3):477-97.

8. Mckay DW. New concept of and approach to clubfoot treatment: section-III evaluation and results. J Pediatr Orthop 1983;3(2):141-8.

9. Crawford AH, Marxen JL, Osterfeld DL. The cincinnati incision: a comprehensive approach for surgical procedures of the foot and ankle in childhood. JBJS Am 1982;64(9):1355-8.

10. Roposch A, Steinwender G, Linhart WE. Implantation of a soft-tissue expander before operation for club foot in children. JBJS Br 1999;81(3):398-401.

11. Simons GW. Complete subtalar release in clubfeet. Part IIcomparision with less extensive procedures. JBJS Am 1985;67(7):1056-65.

12. Lohia LK, Meena S, Kanojia RK. Comparative study of complete subtalar release and Joshi's external stabilization system in the management of neglected and resistant idiopathic clubfoot. Foot Ankle Surgery 2015;21(1):16-21.
13. Grahm GP, Dent CM. Dillwyn evans operation for relapsed club foot. Long-term results. JBJS Br 1992;74(3):445-8.

14. Lichtblau S. A medial and lateral release operation for club foot. A preliminary report. JBJS Am 1973;55(7):1377-84.

15. DeRosa GP, Stepro D. Results of posteromedial release for the resistant clubfoot. J Paed Orthop 1986;6(5):590-5.

16. Evans D. Relapse clubfoot. JBJS Br 1961;43-B:722-33.

17. Lundberg BJ. Early dwyer operation in talipes equinovarus. Clin Orthop Relat Res 1981;154:223-7.

18. Herold HZ, Torok G. Surgical correction of neglected club foot in the older child and adult. JBJS Am 1973;55(7):1385-95.

19. Dekel S, Weissman SL. Osteotomy of the calcaneus and concomitant planter stripping in children with talipes cavo-varus. JBJS Br 1973;55(4):802-5.

20. Lloyd-Robert GC, Swann M, Catterall A. Medial rotational osteotomy for severe residual deformity in club foot. A preliminary report on a new method of treatment. JBJS Br 1974;56(1):37-43.

21. Davidson RS. Clubfoot salvage: a review of the past decade's contributions. J Pediatr Orthop 2003;23(3):4108.

22. Cummings RJ, Davidson RS, Armstrong PF, et al. Congenital clubfoot. JBJS Am 2002;84-a(2):290-308.

23. Saif UM, Noor-ul FMK, Shahjahan M, et al. Management of congenital talipes equinovarus (CTEV) by ponseti casting technique in neonates: our experience. J Neonatal Surgery 2013;2(2):17. 